\title{
Microstructural effects of phosphorus on pressure die cast Al-12Si components(')
}

\author{
B. Suárez-Peña*, J. Asensio-Lozano**, J.I. Verdeja-Gonzalez**and J.A. Pero-Sanz Elorz***
}

\begin{abstract}
The refinement of cuboidal silicon in eutectic Al-Si alloys by phosphorus additions used to manufacture pressure die cast components was studied. The results show that the addition of phosphorus in the form of AlFeP mother alloy before process degassing, leads to the best refinement of the size of the Si-cuboids phase, among several phosphorus additions analysed in the present research.
\end{abstract}

Keywords

Aluminum alloys. Phosphorous additions. Si-cuboids refinement. Quantitative metallography.

\section{Efectos microestructurales de la adición de fósforo a la aleación Al-12Si en piezas fabricadas por colada a presión}

\begin{abstract}
Resumen
Se ha estudiado el afino del silicio cuboidal en aleaciones eutécticas Al-Si por acción del fósforo, en piezas obtenidas mediante la técnica de fundición a presión. Tras la adición de fósforo en pruebas industriales, en las que dicho elemento se incorpora al baño con diversas composiciones, los mejores resultados se obtienen con la adición de la aleación madre AlFeP, previa al desgasificado industrial.
\end{abstract}

Palabras clave

Aleaciones de aluminio. Adición de fósforo. Afino del Si-cuboidal. Metalografía cuantitativa.

\section{INTRODUCTION}

Aluminium-silicon alloys constitute one of the main groups of cast aluminum alloys. The eutectic alloy has a Si content of approximately $12 \mathrm{wt}$. \%; its microstructure being formed by the eutectic of $\alpha-\mathrm{Al}$ with silicon. However, certain factors, such as the content of $\mathrm{Sr}, \mathrm{Na}, \mathrm{Ca}, \mathrm{Cu}, \mathrm{Ni}, \mathrm{Mg}$ or Fe and the solidification rate, may significantly alter the microstructure expected from the equilibrium phase diagram, with the possible appearance of primary $\alpha-\mathrm{Al}$ dendrites as well as silicon particles. The appearance of this latter phase leads to a reduction in the toughness, ductility and wear resistance of these alloys. High wear resistance, good castability and machinability require a fine, uniform distribution of the Si-cuboids [1 and 2]. Recent developments have shown the possibility of conducting novel welding techniques such as friction stir welding on $10 \% \mathrm{Si}$ hypoeutectic Al-Si alloys containing $\mathrm{Mg}{ }^{[3]}$ which preclude the possibility of extending the technique to nearly eutectic compositions, without an adverse effect on the fatigue behaviour due to the limited growth of pre-existing Si cuboids.

Gruzsleski ${ }^{[2]}$ has shown that primary silicon does not nucleate on the impurities that are usually present in these alloys. The refining of silicon is generally achieved by means of the addition of phosphorus. Phosphorus reacts with aluminium in the liquid state and produces a fine dispersion of aluminum phosphide (AlP), with a crystalline structure very similar to that of silicon. Phosphorus thus serves as an

(·) Trabajo recibido el día 6 de octubre de 2006 ya aceptado en su forma final el día 3 de enero de 2007

* Department of Materials Science and Metallurgical Engineering, Technical School of Industrial Engineering, University of Oviedo, Campus de Viesques, Carretera de Castiello de Bernueces, s/n, E-33203 Asturias, SPAIN.

** Department of Materials Science and Metallurgical Engineering, The School of Mines, University of Oviedo, c/ Independencia-13, Oviedo, E-33004 Asturias, SPAIN.

*** Department of Engineering Materials, The School of Mines, Polytechnical University of Madrid, c/ Rios Rosas-21, Madrid, E-28003 Madrid, SPAIN. 
MICROSTRUCTURAL EFFECTS OF PHOSPHORUS ON PRESSURE DIE CAST AL-12SI COMPONENTS EFECTOS MICROESTRUCTURALES DE LA ADICIÓN DE FÓSFORO A LA ALEACIÓN AL-12SI EN PIEZAS FABRICADAS POR COLADA ...

effective heterogeneous nucleation site for the silicon phase. Other modifiers of the silicon phase, such as $\mathrm{Mg}, \mathrm{W}, \mathrm{S}$ and La, are not usually employed in industry for a number of reasons ${ }^{[2]}$.

Many fluxes contain red phosphorus together with salts that serve to prevent the rapid oxidation/ combustion of elemental phosphorus, thus improving its yield in the melt $t^{[4}$ and 5$]$. Other additives have also been developed following these same principles, namely $\mathrm{AlFeP}{ }^{[6]}, \mathrm{AlCuP}^{[7]}$ and $\mathrm{AlNiP}{ }^{[8]}$. These are more effective against oxidation, though much more costly. Phosphorous recovery varies in relation to the type of additive employed and the addition technique, but is always low, between 5 and 20 wt. \%. The optimum level of phosphorus for favouring a suitable refinement of the Si-cuboids is between 0.003 and 0.015 wt. \%, depending on casting conditions ${ }^{[2]}$. In the present study, phosphorus was added to the mix in the form of red phosphorus, and as an Al-15Fe-5P master alloy when casting Al-Si escalator steps.

\section{EXPERIMENTAL PROCEDURE}

The nominal compositions of the Al-12Si and prerefined Al-12Si commercial alloys employed in the present study are listed in table I. The experimental procedure followed was: in the two initial tests leading, the first test had no P present in the composition and the second one, $\mathrm{P}$ was present forming part of the chemistry of phosphorus preconditioned ingots, used as raw material for melting. None of these two first tests had P added in the production route for the manufacture of escalator steps; in the third and fourth tests, $0.003 \mathrm{wt} . \% \mathrm{P}$ was added in the forms of red phosphorus and the Al$15 \mathrm{Fe}-5 \mathrm{P}$ master alloy, respectively (Table II).

The manufacturing process followed was: after melting the alloy approximately $700 \mathrm{Kg}$ was poured into a treatment ladle at a temperature of approximately $750^{\circ} \mathrm{C}$ in each of the tests. Subsequently, phosphorus was added to the mix in the form of rods of red phosphorus or as the $\mathrm{Al}-15 \mathrm{Fe}-5 \mathrm{P}$ master alloy. The melt was degassed with nitrogen by means of a rotor-
Table II. Details of the concentration of $\mathrm{P}$ in testing samples after atmospheric solidification in preheated die

Tabla II. Contenido en P de las muestras enfriadas al aire en molde metálico precalentado.

\begin{tabular}{ccc}
\hline Heat No. & $\begin{array}{c}\text { P content } \\
\text { (ppmwt) }\end{array}$ & $\begin{array}{c}\text { P-containing } \\
\text { additive }\end{array}$ \\
\hline 1 & - & - \\
2 & 10 & Pre-refined alloy \\
3 & 30 & $\begin{array}{c}\text { Red P } \\
\text { Al-15Fe-5P }\end{array}$ \\
\hline
\end{tabular}

injector system ${ }^{[9]}$ and the specimens were poured into a die pre-heated to $340^{\circ} \mathrm{C}$. Finally, the melt was transferred to the holding furnace at a temperature of $675^{\circ} \mathrm{C}$. A fraction of liquid was transferred into the hot chamber injection system in which the escalator steps are moulded. One escalator steps per alloy condition was used for analysis.

Samples of each experimental composition were obtained for metallographic observation in the gravity die-cast condition after pouring liquid into a die preheated to $340^{\circ} \mathrm{C}$. In the pressure die casting condition, samples were extracted by cutting a portion of metal from the central rib of the escalator step. These samples were prepared by conventional mechanical grinding and polishing and etched with an aqueous solution of $0.5 \% \mathrm{HF}$ in order to reveal the microstructure under light optical microscopy. Observations were performed using a Nikon Ephiphot metallograph connected to a Kappa ImageBase image analyser.

Evaluation of the volume fraction and the particle diameter of the silicon particles was determined by quantitative metallographic techniques such as point counting, linear and areal analysis ${ }^{[10-14]}$. For the point count method the percentage of relative error for the volume fraction of Si cuboids,

$$
\mathrm{RE} \%=\frac{\mathrm{s}(\mathrm{Vv})}{\mathrm{Vv}} \times 100
$$

Table I. Chemical composition of the Al-12Si commercial alloys in wt. \%.

Tabla I. Composición química de la aleación comercial Al-12Si (\%-peso).

\begin{tabular}{ccccccccccc}
\hline \multicolumn{1}{c}{ Elements } & $\mathrm{Si}$ & $\mathrm{Fe}$ & $\mathrm{Cu}$ & $\mathrm{Mn}$ & $\mathrm{Mg}$ & $\mathrm{Ni}$ & $\mathrm{Ti}$ & $\mathrm{Sr}$ & $\mathrm{Cr}$ & $\mathrm{P}$ \\
\hline Commercial alloy & 12.32 & 0.72 & 0.03 & 0.14 & 0.03 & 0.03 & 0.006 & 0.001 & 0.008 & - \\
Pre-refined alloy & 12.26 & 0.75 & 0.04 & 0.18 & 0.02 & 0.006 & 0.10 & 0.001 & 0.004 & 0.001 \\
\hline
\end{tabular}


was calculated after conducting the analysis over 25 micrographs, or failing that, 200 particles. And thereafter determining the values for the standard error of the volume fraction, $s\left(\mathrm{~V}_{\mathrm{v}}\right)$ among the different evaluated fields, as well as the mean value of the volume fraction, $\bar{V}_{\mathrm{v}}$, in all the studied areas. The relative error was found no to exceed $10 \%$. As for the determination of the particle size of Si cuboids obtained by the linear analisys, the relative errors,

$$
\frac{s(d p)}{d_{p}} \times 100
$$

were calculated from each particle distribution after evaluation of several hundreds of individual features over 25 micrographs, or failing that, 360 particles The resulting relative error were smaller than $8 \%$ in all cases. A JEOL JSM-6100 scanning electron microscope (SEM) connected to an Oxford Inca Energy 200 energy dispersive microanalyzer was used to characterize minor phases, mainly Si-cuboids.

\section{RESULTS}

\subsection{Influence of phosphorous additions on the Al-12Si die-cast alloy}

In the gravity die-cast solidified condition, the Al12Si commercial alloy exhibits a microstructure that consists of silicon cuboids and eutectic silicon phases
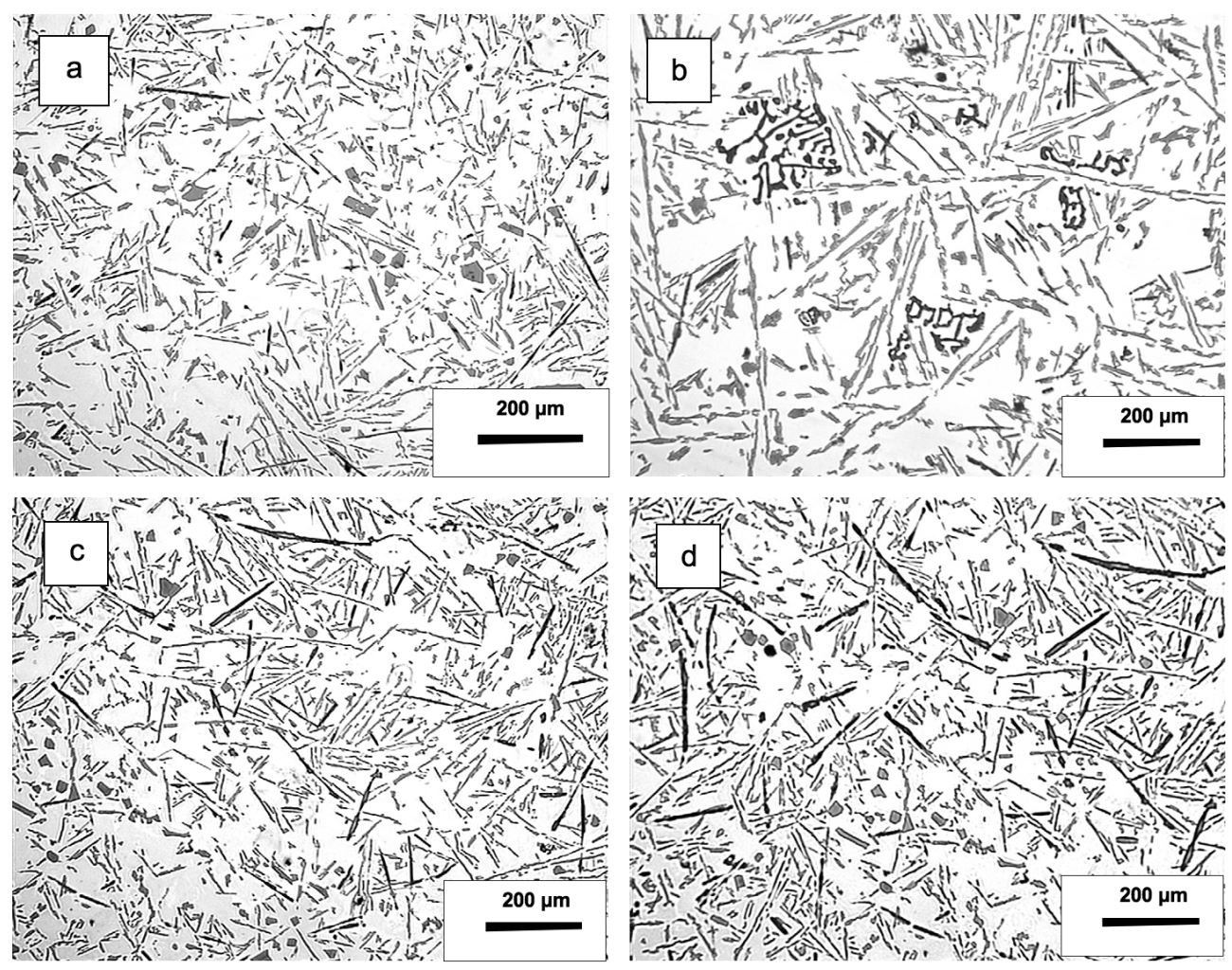

Figure 1. Light optical metallography of the Al-12Si alloy solidified under atmospheric die cast conditions: (a) commercial alloy with no P added showing polyhedral Si particles in light grey; (b) phosphorous pre-refined commercial alloy microstructure with small and irregular Si-cuboids in light grey and the $\alpha$-AlFeSi intermetallic showing its dendritic structure in dark grey. Microstructure of the commercial alloy treated with red $\mathrm{P}$ (c) and with AIFeP (d), after degassing stage of the process route showing the acicular nature of the intermetallic $\beta$ compound.

Figura 1. Metalografía óptica de reflexión de la aleación Al-12Si solidificada en molde metálico a presión atmosférica: (a) aleación comercial sin $P$ añadido, en la que se observan partículas poliédricas de Si cuboidal, en color gris claro; (b) aleación comercial preafinada con P, con presencia de cuboides de Si pequeños e irregulares en tono gris claro, junto a intermetálicos de $\alpha$-AlFeSi con morfología dendrítica, en tonalidad gris oscura. Microestructura de la aleación comercial tras desgasificado y posterior adición de fósforo rojo (c) y en forma de AlFeP (d). En ambos casos es posible distinguir la morfología acicular del compuesto intermetálico $\beta$. 
MICROSTRUCTURAL EFFECTS OF PHOSPHORUS ON PRESSURE DIE CAST AL-12SI COMPONENTS EFECTOS MICROESTRUCTURALES DE LA ADICIÓN DE FÓSFORO A LA ALEACIÓN AL-12SI EN PIEZAS FABRICADAS POR COLADA ...

embedded in an $\alpha$-Al matrix (Fig. 1 a)). Needles of the $\alpha$-AlFeSi intermetallic compound, common in Al-Si alloys, can also be seen in figure $1^{[15]}$. This acicular phase is accompanied by the $\alpha$-AlFeSi intermetallic phase, which presents a dendritic structure, in the experimental heat in which phosphorus was added in the form of the pre-refined commercial alloy (Fig.1 b)). Crystals of the intermetallic compound with a polyhedral morphology were detected in the alloy to which red phosphorus was added (Heat no. 3) during ladle treatment (Fig. 2).

The data in table III indicate a slight decrease in the volume fraction of the silicon cuboids in the samples with phosphorus in their compositions. Moreover, a decrease in the mean particle size of the silicon particles was estimated at approximately the same ( $\sim 18 \%)$ after the addition of phosphorus, Table III and figures $1 \mathrm{c}$ ) and d). The largest sizes of silicon cuboids were observed in the samples in which phosphorus was in the form of the pre-refined commercial alloy (Table III and Fig. 1 b)).

\subsection{Influence of phosphorous additions on pressure die-cast samples}

Table III shows that the application of pressure provides a reduction of the volume fraction of

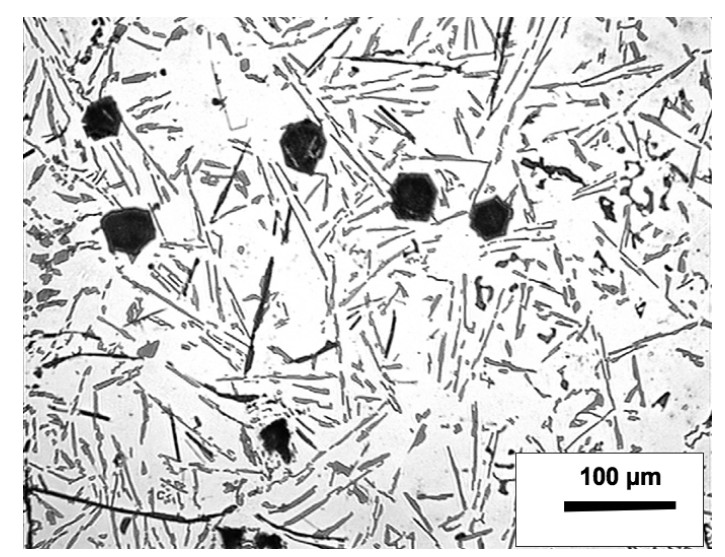

Figure 2. Polyhedral morphology of the AlFeSi intermetallic precipitates revealed in dark grey (brown-red in colour) present in the commercial $\mathrm{Al}-12 \mathrm{Si}$ atmospheric die cast conditions alloy being refined with red $P$.

Figura 2. Morfología poliédrica de los compuestos intermetálicos AlFeSi presentes en la aleación comercial Al-12Si en tonalidad gris oscura / negra (marrón-rojiza en color), tras afino con fósforo rojo y enfriamiento al aire en molde metálico.
Table III. Volume fraction $\left(\mathrm{V}_{\mathrm{v}}\right)$ and particle diameter $\left(\bar{d}_{p}\right.$ of cuboidal silicon. The $95 \%$ Confidence Limit for every determination of the aforementioned metallographic parameters has been included.

Tabla III. Fracción en volumen $\left(V_{y}\right)$ y tamaño $\left(\bar{d}_{p}\right)$ del silicio cuboidal. Se incluyen los limites de confianza al 95\% de cada determinación para ambos parámetros metalográficos.

\begin{tabular}{|c|c|c|c|c|}
\hline \multirow{2}{*}{ Heat No. } & \multicolumn{2}{|c|}{$\begin{array}{l}\text { Atmospheric } \\
\text { die casting }\end{array}$} & \multicolumn{2}{|c|}{$\begin{array}{l}\text { Pressure die } \\
\text { casting }\end{array}$} \\
\hline & $\mathrm{V}_{\mathrm{V}} \pm \mathrm{CL}_{(\%)}$ & $\bar{d}_{p} \frac{ \pm L_{95 \%}}{(\mu \mathrm{m})}$ & $\mathrm{V}_{\mathrm{V}} \pm \mathrm{CL}_{(\%)}$ & $\bar{d}_{p} \pm C_{(\mu m)}$ \\
\hline 1 & $2.27 \pm 0.31$ & $19.9 \pm 1.6$ & $0.71 \pm 0.10$ & $3.8 \pm 0.3$ \\
\hline 2 & $2.03 \pm 0.27$ & $24.8 \pm 3.9$ & $0.70 \pm 0.11$ & $3.8 \pm 0.3$ \\
\hline 3 & $1.99 \pm 0.35$ & $16.4 \pm 1.1$ & $0.79 \pm 0.12$ & $4.4 \pm 0.3$ \\
\hline 4 & $1.90 \pm 0.26$ & $16.6 \pm 1.8$ & $0.77 \pm 0.10$ & $2.1 \pm 0.1$ \\
\hline
\end{tabular}

cuboidal silicon regardless of $\mathrm{P}$ additions. This result is in good agreement with the observations made in a former research by the authors ${ }^{[16-18]}$ where nearly eutectic samples transform into hypoeutectic ones by the application of pressures oscillating in the range of $360-400 \mathrm{~atm}$. As a result, smaller liquid fractions solidify in the coupled zone thus minimizing the formation of cuboidal $\mathrm{Si}^{[19]}$.

Figure 3 shows the microstructures corresponding to the samples taken from the central ribs of the escalator steps both with and without phosphorous additions. The high cooling rates, in combination with the pressure that is exerted on the melt during solidification, lead to microstructural refinement evaluated by the mean Feret diameter, as well as to a uniform distribution of the phases present as compared to the corresponding microstructures solidified under atmospheric conditions in a preheated die mould. It of the Al-12Si alloys commences with the solidification of the Si-cuboidal particles and the $\alpha$-Al dendrites. It then progresses in the residual liquid with the formation of an alternating lamellar structure of $\mathrm{Si}$ and $\alpha$-Al through the eutectic reaction. The resulting microstructure at room temperature consisted of fine grains of $\alpha$-Al phase with a quasi-equiaxed morphology, a low volume fraction of extremely fine Si cuboids (Figs. 4 and 5), and a lamellar eutectic with fine silicon needles. The $\beta$-AlFeSi intermetallic compound is mainly present with an acicular morphology (Fig.3) appearing coarser when red phosphorus was added. Small amounts of the intermetallic compound that are polygonal in shape are observed in the sample containing AlFeP (Fig. 3 d)). 

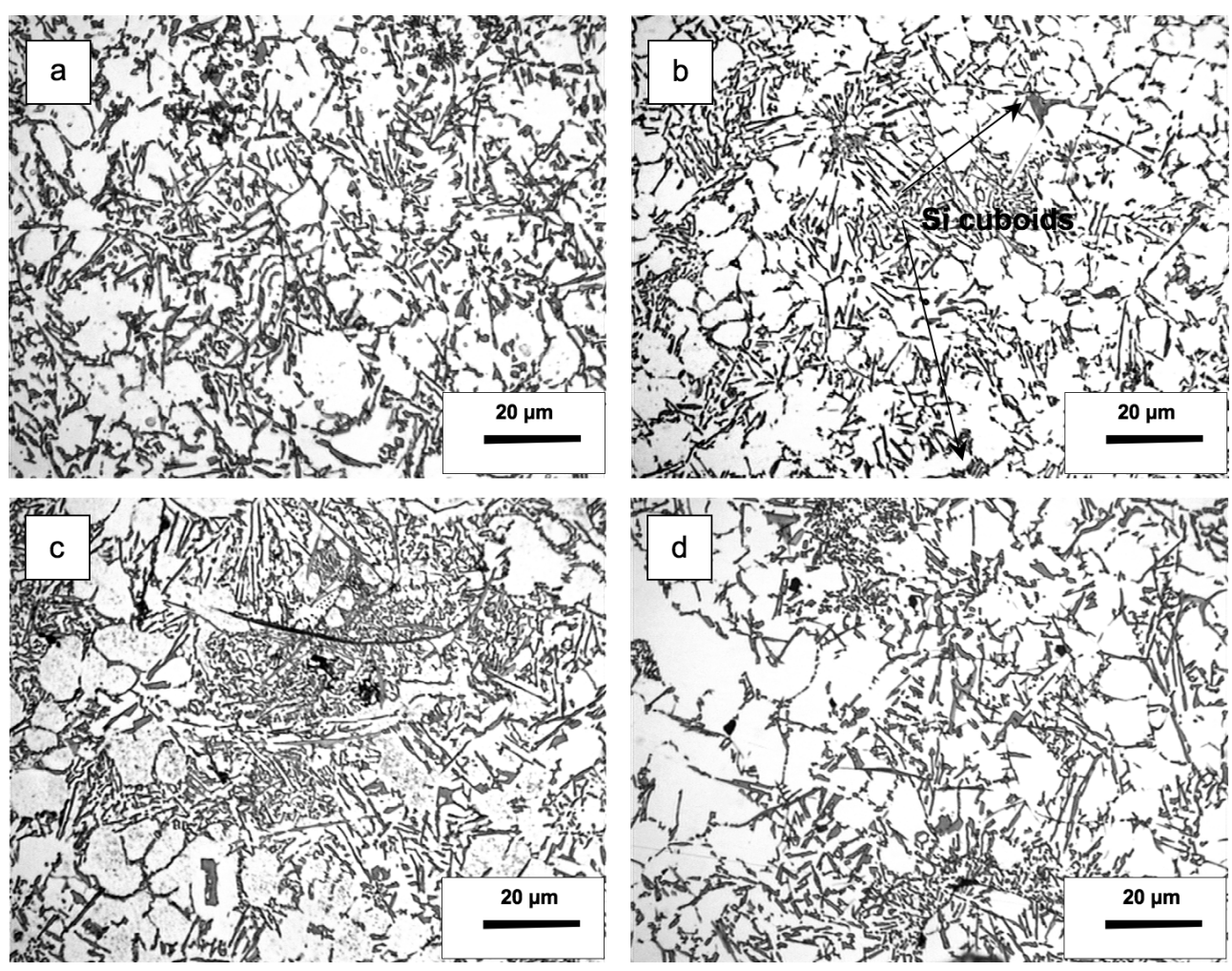

Figure 3. Light optical metallography of pressure die cast samples: (a) commercial alloy microstructure showing fine grains of the $\alpha$-Al phase with quasi-equiaxed morphology and extremely fine cuboids of silicon embedded in a fine eutectic. Needles of $\beta$ intermetallic can also be seen in dark grey; (b) $P$ pre-refined commercial alloy microstructure depicting the isolated nature of the acicular eutectic constituent; (c) after adding red phosphorus as a refining agent to the commercial alloy; and (d) with the AIFeP master alloy likewise added for refinement.

Figura 3. Microestructuras obtenidas mediante observación por microscopía óptica de reflexión en muestras procedentes de piezas fabricadas mediante el método de fundición a presión: (a) en la aleación comercial se muestran los granos de Al- $\alpha$ con morfología casi equiáxica, junto con finísimos cuboides de Si, embebidos en una fina matriz eutéctica; (b) aleación comercial preafinada con $P$ en la que se observa la naturaleza acicular del constituyente eutéctico; (c) aleación afinada con fósforo rojo; y, (d) aleación afinada con fósforo añadido de modo análogo al anterior en forma de aleación madre AlFeP.

SEM analysis of the samples (Figs. 4 and 5) confirmed the polygonal morphology of the cuboids in all cases.

\section{DISCUSSION}

Schneider ${ }^{[7]}$ reported that the size of silicon cuboids in a eutectic Al-Si alloy decreased from $200 \mu \mathrm{m}$ to $70 \mu \mathrm{m}$ when $30 \mathrm{ppm}$ wt. P was added. The refinement by phosphorus that silicon cuboids verified for the commercial alloy (Heat no. 1) under atmospheric die cast conditions, can be seen in Table II. It reached a constant value of $\sim 16.6 \%$ at $30 \mathrm{ppm}$ wt. P, regardless the phosphorus is added as red phosphorus (Heat no.
3) or as Al-15Fe-5P mother alloy (Heat no. 4) during ladle treatment. The results are in good agreement with the trend observed by Schneider, being somewhat different the size reduction ratio, somewhat smaller in the present work. A possible reason for this difference in the reduction ratio might be connected to a higher effectiveness of $\mathrm{P}$ in reducing the size of coarser $\mathrm{Si}$ cuboids ${ }^{[20]}$. However, it can be seen that the highest value of the particle diameter was found in Heat no. 2, corresponding to the prerefined commercial alloy. This is indicative of the scant effect of $\mathrm{P}$ as a refiner when the levels are around $10 \mathrm{ppm} w \mathrm{wt}$. or less.

After analyzing the silicon cuboids in the sample taken when red phosphorus was added in the ladle treatment, no phosphorus content was detected 

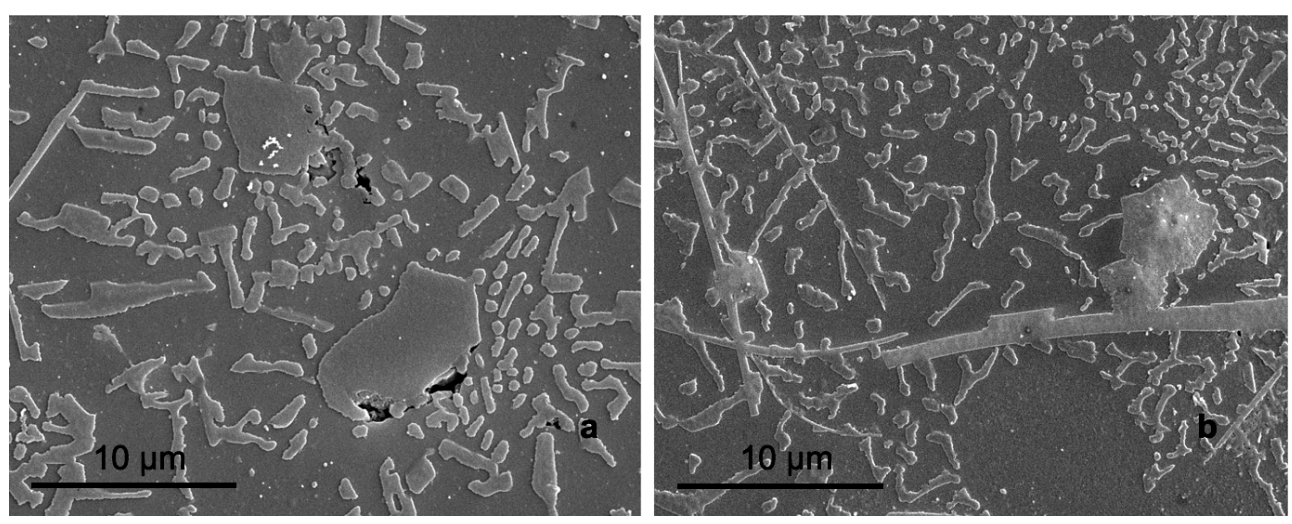

Figure 4. SEM micrographs corresponding to the pressure die cast analysed samples showing the cuboidal morphology of the Si particles in: (a) Al-12Si commercial alloy and (b) in the P pre-refined commercial alloy.

Figura 4. Micrografías electrónicas de barrido correspondientes a muestras procedentes de piezas fabricadas mediante fundición a presión. Se aprecia la morfología cuboidal de las partículas de Si: (a) aleación comercial Al-12Si y (b) aleación preafinada con P.

\begin{tabular}{ccc}
\hline $\begin{array}{c}\text { Element } \\
\text { (wt. \%) }\end{array}$ & 1 & 2 \\
\hline $\mathrm{Al}$ & 40.0 & 60.45 \\
\hline $\mathrm{Si}$ & 60.0 & 32.33 \\
\hline $\mathrm{P}$ & -- & 7.23 \\
\hline
\end{tabular}
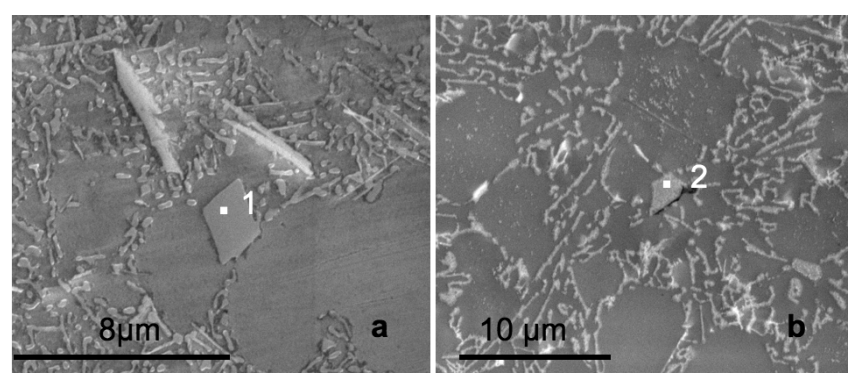

Figure 5. SEM micrographs corresponding to pressure die cast samples in Al-12Si: (a) with red phosphorus added and (b) with AIFeP added. And associated analysis of silicon cuboids in particularized points.

Figura 5. Micrografías electrónicas de las muestras obtenidas a partir de piezas fabricadas mediante fundición a presión, en la aleación Al-12Si a la cual se le adicionó fósforo, como afinante en forma de: (a) Fósforo rojo y (b) AlFeP. Se adjuntan los resultados de los análisis puntuales efectuados sobre cuboides de Si.

(Fig. 5 a)). However, the presence of phosphorus was detected in the specimen to which AlFeP was added (Fig. 5 b)). The results obtained by means of the application of quantitative metallographic techniques (Table III) support this finding. After the addition of red phosphorus, no decreases in the size of the $\mathrm{Si}$ phase of the pressure die cast parts was measured. A possible explanation for these findings may lie in the losses that the refining agent experiences as a result of a possible oxidation/combustion of the elemental phosphorus dissolved in the melt, possibly due to the high dwell times at elevated temperature inside the holding furnace ${ }^{[21]}$. A slight increase in the volume fraction of the cuboids was observed after the addition of $\mathrm{P}$ to the ladle with respect to the samples in the unrefined condition and the pre-refined one. The data available in the literature ${ }^{[22]}$ underlines that there is no need for the addition of phosphorus as a refiner of the Si cuboids when the alloys are processed by means of high pressure die casting, owing to the reduction in size obtained by the high cooling rates involved. However, the results obtained in this study, as regards the size of the Si-cuboids, indicate that the addition of phosphorus in the form of $\mathrm{AlFeP}$ is capable of producing a further refinement in the size of this phase of approximately $45 \%$.

It can be seen that the largest mean particle diameter of the silicon cuboids, in the pressure die casting condition corresponded to the sample refined by adding red phosphorus. The particle size is larger 
than that obtained by adding $\mathrm{Al}-15 \mathrm{Fe}-5 \mathrm{P}$ to the melt in the same stage of processing. According to the technical literature ${ }^{[22]}$, after the formation of the AlP particles, these tend to coalesce by clustering when the treated liquid dwells for relatively long times. In the industrial process followed in this study, this dwell time corresponded to the time elapsed from the degassing stage in the holding furnace until the injection of the treated melt in the dies. As a result, the number of nucleation sites for the Si cuboids could have decreased significantly thus leading to an increase in the particle diameter. The fact that the AlP particles are more readily available when phosphorus is added to the molten metal in the form of red phosphorus as opposed to Al-Fe-P also favors coalescence at earlier stages, thus explaining the difference in diameter found in this research.

\section{CONCLUSIONS}

In atmospheric die cast samples, a reduction in size of the Si particles of approximately $17 \%$ was obtained after the addition of $\mathrm{P}$ during the ladle metallurgy treatment.

The atmospheric die cast sample obtained from the pre-refined commercial alloy containing $\mathrm{P}$ exhibited the largest size of Si cuboids. This result is attributable to the low initial percentage of this element and to further losses due to oxidation.

After the addition of red $\mathrm{P}$ during ladle metallurgy, no reductions were observed in the size of the $\mathrm{Si}$ phase of the pressure die cast parts, indicating a possible fading effect that translates into less refined Si particles.

In the present study, it was possible to obtain a further particle diameter refinement of approximately $45 \%$ of the already small Si cuboids obtained by rapid cooling during pressure die casting by adding $\mathrm{P}$ in the form of AlFeP. This result implies a certain degree of novelty, since most of the technical literature reviewed stresses that the addition of $\mathrm{P}$ to pressure die casting is inefficient.

\section{Acknowledgements}

The authors wish to express their gratitude to the University of Oviedo Vice-Rectorate for Research for financial support in the translation of the manuscript. We also want to convey our thanks to Professor Dr. J.J. Del Campo, former manager of the Thyssen-Krupp Güss factory at its location in Mieres, Spain, for having granted access to materials and facilities in the factory.

\section{REFERENCES}

[1] B. HESHMATPOUR, Light Metals (1996) 687695.

[2] J. E. GRUZSLESKI AND B. M. CLOSSET, The treatment of liquid Al-Si alloys, American Foundrymen's Society Inc, Des Plaines (IL),1990, p. 13.

[ 3] J.M. ALBUQUERQUE, P.A. RAMOS, M.A. GOMES, AND A.C. CRUZ, Rev. Metal. Madrid 41 (2005) 126-132.

[4] A. P. BATES AND D. S. CALVERT, Foundryman 59 (1996) 119-133.

[5] B. SUÁREZ-PEÑA, Tesis Doctoral, Universidad de Oviedo 2006.

[6] D. W. MANSON, Light Metals (1995) 1019-1023.

[7] W. SCHNEIDER, Light Metals (1993) 815-820.

[8] H. J. KIM, Mater. Sci. Technol. 19 (2003) 915-918.

[9] M.A. RAMIREZ, F. CONTRERAS AND C. GONZALEZ, Rev Metal. Madrid 42 (2006) 185-202.

[10] G. F. VANDER VOORT, Metallography: Principles and Practice, ASM International. Materials Park, OH, 1994, pp. 31-34.

[11] R. L. HIGGINSON AND C. M. SELLARS, Worked examples in quantitative metallography, Institute of Metals, Maney Publishing, London, U. K., 2003.

[12] J. ASENSIO, Curso de Metalografía Cuantitativa, E.T.S.I.M.O, Oviedo, España, 1992.

[13] J. MUIRHEAD, J. CAWLEY, A. STRANG, C. A. ENGLISH AND J. TITMARSH, Mater. Sci. Technol. 16 (2000) 1160-1166.

[14] B. ROEBUCK, Mater. Sci. Technol. 16 (2000) 1167-1174.

[15] M. DA SILVA AND J. M. RODRÍGUEZIBABE, Rev. Metal. Madrid 39 (2003) 452-460.

[16] J. ASENSIO-LOZANO AND B. SUAREZPEÑA, Mat. Char. 56 (2006) 169-177.

[17] J. ASENSIO-LOZANO AND B. SUAREZPEÑA, Mat. Char. 56 (2006) 178-189.

[18] B. SUÁREZ-PEÑA AND J. ASENSIOLOZANO, Mat. Char. 57 (2006) 218-226.

[19] J. E. GRUZLESKY, Microstructure Development during metal casting, American Foundrymen's Society Inc., Des Plaines (IL), 2000, pp. 204-211.

[20] J. E. GRUZLESKY, Microstructure Development during metal casting, American Foundrymen's Society Inc., Des Plaines (IL), 2000, pp. 110-117.

[21] W. J. KYFFIN, W. M. RAINFORTH AND H. JONES, Mater. Sci. Technol. 17 (2001) 901-905.

[22] J. E. GRUZSLESKI AND B. M. CLOSSET, The treatment of liquid Al-Si alloys, American Foundrymen's Society Inc, Des Plaines, (IL) 1990, pp. 107-126. 